
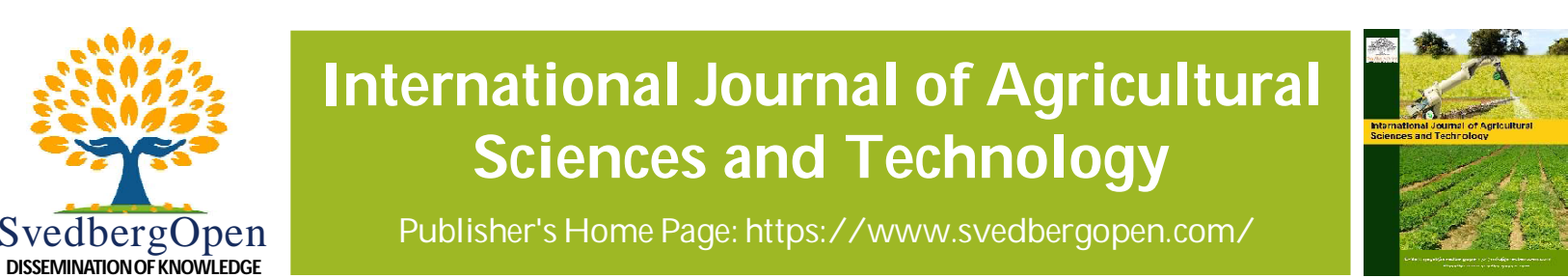

\title{
Rice phenology and growth simulation using DSSAT-CERES-Ricecrop model under the different temperatures changing with climatic condition
}

\author{
Shams Shaila Islam ${ }^{1 *}$, Jirawat Sanitchon ${ }^{2}$ and Ahmed Khairul Hasan ${ }^{3}$ \\ ${ }^{1}$ Department of Agronomy, faculty of Agriculture, Hajee Mohammad Danesh Science and Technology University, Dinajpur-5200, Bangladesh. \\ Email: shaila.hmdstu@gmail.com \\ ${ }^{2}$ Faculty of Agriculture, Khon Kaen University, Khon Kaen - 40002, Thailand. Email: jirawat@kku.ac.th \\ ${ }^{3}$ Department of Agronomy, faculty of Agriculture, Bangladesh Agricultural University-2202, Mymensingh. Email: akhasan@bau.edu.bd
}

\section{Article Info}

Volume 1, Issue 2, May 2021

Received : 20 December 2020

Accepted : 09 March 2021

Published : 05 May 2021

doi: 10.51483/IJAGST.1.2.2021.1-11

\begin{abstract}
This research paper aims to evaluate the performance of DSSAT CERES-Rice model in simulating the impact of different $\left(28^{\circ} \mathrm{C}, 30{ }^{\circ} \mathrm{C}\right.$ and $\left.32^{\circ} \mathrm{C}\right)$ increased temperatures change with the relations of five upland rice genotypes (Dawk Pa-yawm, Mai Tahk, Bow Leb Nahng, Dawk Kha 50 and Dawk Kahm) on grain yield for future crop management. Results showed that temperature significantly affected grain yields, harvest index, flowering and maturity date which indicate that medium temperature $\left(30^{\circ} \mathrm{C}\right)$ gave highest grain yield bearing genotype Dawk Kahm $(6,700 \mathrm{~kg} / \mathrm{ha})$ whereas at maximum temperature $\left(32^{\circ} \mathrm{C}\right)$, simulated grain yields varied from 3094 to $6460 \mathrm{~kg} / \mathrm{ha}$. Root Mean Square Error (RMSE) values of simulated and observed data less than $10 \%$ indicated that grain weight, leaf area index, tillers number and harvest index had more consistency agreement with the yield. Thus, it was proved that the CERES-Rice crop simulation model was more useful as a tool for different phenological traits under changing temperature conditions. And the model approximated grain yields at different temperatures with reasonable accuracy.
\end{abstract}

Keywords: DSSAT-CERES-Rice model, Grain yield, Phenological traits, Temperature effect, Upland rice

(C) 2021 International Journal of Agricultural Sciences and Technology. This is an open access article under the CC BY license (https://creativecommons.org/licenses/by/4.0/), which permits unrestricted

use, distribution, and reproduction in any medium, provided you give appropriate credit to the original author(s) and the source, provide a link to the Creative Commons license, and indicate if changes were made.

\section{Introduction}

Model simulation is one of the most imperative tools in the current world for analyzing the utility of parameters related to meteorological, soil and plant aspects, to predict the crop yield and growth features (Lone et al., 2016). Rice (Oryza sativa L.) is an essential cereal crop nourishing near about half of the world's populations by contributing 50 to $80 \%$ of regular caloric consumption (Amirjani, 2011; FAO, 2012). It is mentioned that Japonica, Javanica and Indica subspecies have different types of ecosystems namely, irrigated, rainfed lowland, deep water and upland rice (Bridhikitti and Overcamp, 2011; Nayak et al., 2019).

Upland rice suffers severely from irregular environmental factors, e.g., air temperature, drought, and precipitation (Jalota, 2010). Temperature is credited by its impact on crop yield, due to production expansion under heat stress conditions that greatly influences the growth duration and pattern of the rice plant (Fahad et al., 2017). During the

\footnotetext{
* Corresponding author: Shams Shaila Islam, Department of Agronomy, faculty of Agriculture, Hajee Mohammad Danesh Science and Technology University, Dinajpur-5200, Bangladesh. Email: shaila.hmdstu@gmail.com
} 
growing season the mean temperature, temperature sum, ranges, distribution pattern and diurnal changes or a combination of these, highly correlated with grain yields had a significant issue (Araus and Slafer, 2011).

Depending on different Representative Concentrate Pathways, increase global mean surface temperatures for 19862005 and 2081-2100 is projected to be in the range of $0.3^{\circ} \mathrm{C}$ to $4.8^{\circ} \mathrm{C}$ (IPCC, 2016). Same changes will also be found in Thailand where average day temperature increase is likely to be $2.0^{\circ} \mathrm{C}$ to $4.0^{\circ} \mathrm{C}$ by 2100 (IPCC, 2013). In developing countries, several studies have recently examined the economic effects of climate change on agricultural production and showed susceptibility of crop agriculture to this change reported by Fazal and Wahab (2013).

Several crop models used from long time to assist crop management practices with explore physiological mechanisms under different environments (Reidsma et al., 2010). The crop models are Decision Support Systems for Agrotechnology Transfer (DSSAT), (ICASA, 2011); Chen et al. (2010) used Agricultural Production System Simulator (APSIM) model for winter wheat and summer corn rotation in simulation of climate and water management (Goyal et al., 2012) used (Hydrus2D) model for simulation of subsurface drip irrigation for onion and ground nut; Crop System Model (CSM) was used by Jat et al. (2017) to simulate grain yield, biomass and water balance of rice crop.

Lizaso et al. (2011) stated DSSAT is a software combination of several dynamic crop simulation models, with the help of soil, daily weather (historical or future), input different management data can predict accurately growth, development and yield of crops to assist farmers in developing long-term plans. CERES (Crop Environment Resource Synthesis)-Rice model in DSSAT software with adjustment of different temperatures can be used to evaluate risk associated uncertainties for upland rice production system (Soler et al., 2017). Due to global warming and climatic risk, the current rice production in Thailand have danger. Because, to fulfill the increase rice demand of ever-growing population pressures, an estimation of likely impact is vital for planning strategies. So, the objectives of the research study were (1) to determine the best temperature schedule with high yielding genotypes and (2) using DSSAT-CSM-Rice model to simulate the impact of different temperatures change on upland rice yield, yield contributing traits and production.

\section{Materials and methods}

\subsection{Plant materials and conduction of experiment}

For simulating the crop growth and yield of upland rice, a field experiment was conducted during (July to December) of 2017 at the research area of Plant Science Department, Faculty of Natural Resources, Prince of Songkla University, Hat Yai Campus ( $7.13^{\circ} \mathrm{N}, 100.26^{\circ} \mathrm{E}$ and 63 meters) Thailand. For this purpose, five popular high yielding upland rice genotypes namely, Dawk Pa-yawm, Mai Tahk, Bow Leb Nahng, Dawk Kha 50 and Dawk Kahm were selected. The experiment was conducted as a split plot using Complete Block Design (CRD) as main plots with three replications. The main plots were five Thai upland rice genotypes and sub plots three different temperatures $\left(28{ }^{\circ} \mathrm{C}, 30{ }^{\circ} \mathrm{C}\right.$ and $\left.32{ }^{\circ} \mathrm{C}\right)$ recorded by using the data logger (UA-002-08 HOBO Pendant, for Temp/Light) and daily solar radiation (MJm-2 day1) was calculated by using weatherman tools in DSSAT v4.7 software.

For this experiment used a limited number of genotypes because selected genotypes have retained 76 characteristics of survival under different temperatures condition. Another important point was that availability of upland condition tolerant genotypes are limited in Thailand. In each treatment consisted of five rows ( 5 meters/row) with five genotypes which were randomized and replicated within each block. Each genotype was planted $30 \mathrm{~cm}$ apart between rows and 25 $\mathrm{cm}$ within the rows among the plots. 15:15:15 N-P-K fertilizers was applied at the rate of $15 \mathrm{~kg}$ of N, P and K ha- 1 as urea, super phosphate, and muriate of potash to the plots before planting. Nitrogen was applied in four equal splits at basal, active tillering, panicle initiation and flowering stages to the individual replication as per the treatment schedule of fertilizer application. Direct rice seeded were done and each pot 2-3 seeded were placed. Irrigation and plant protection measures were followed uniformly in all the pots as per the requirement. Insect pests were controlled by the application of $10 \mathrm{ml}$ per $1 \mathrm{LCypermethrin} \mathrm{10 \%} \mathrm{w/v} \mathrm{EC} \mathrm{and} 2.5 \mathrm{ml}$ per $1 \mathrm{LBenfuracarb} 20 \% \mathrm{w} / \mathrm{v}$ EC with water. The crop management data (i.e., phenological data) required for the simulation of the model include planting date, $50 \%$ germination date, $100 \%$ germination date, flowering and maturity, tillers number, panicles number, leaf area index, grain yield, biomass and 1000 grain weight were recorded at the harvesting stage.

\subsection{Description of the DSSAT - CERES-Rice model}

DSSAT-CERES-Rice present in DSSAT v4.7 which is an advanced physiologically based model was used to calibrate and evaluate the crop simulation model. Genetic coefficients for the five upland rice genotypes were used to calibrate 
CSM-CERES-Rice model. Soil analysis was done before started of the experiments to analyze soil fertility and to carryout proper fertilizer management. Weather parameters including maximum and minimum temperatures, rainfall with air intensity were recorded by using the data logger (UA-002-08 HOBO Pendant, for Temp/Light) and daily solar radiation (MJm-2 day-1) was calculated by using weatherman tools in DSSAT v4.7. Mai Tahk genotype was used as border crop to avoid the varietal errors.

To run the model, the following five input files were created:

1. Daily weather data: Maximum and minimum air temperatures, precipitation, rainfall, and solar radiation (derived from sunshine hour data) were collected from the weather station of Kho Hong Agro meteorological office, Hat Yai, Thailand.

2. Soil data: Collected input data on soil characteristics at 5, 10, and $20 \mathrm{~cm}$ depths before planting. Soil classes, organic carbon (\%), sand, silt, clay (\%), soil texture, soil pH in water, field capacity (\%), organic carbon (\%), cation exchange capacity, total nitrogen, potassium and phosphorus, potential root distribution and depth were taken.

3. Management practices: Planting density, planting date, irrigation, weeding, plant row spacing, sowing depth, amount and types of fertilizers, insecticide application was done whenever necessary.

4. Plant profile data: Sowing date, emergence date, flowering date, physiological maturity date, panicle initiation (when $50 \%$ and $100 \%$ of the crop had reached those stages) plant population, plant height, tillers number, tops weight (grain weight), harvest index and grain yield per genotype, i.e., grain yield per area of production.

5. Genetic coefficients file: The genetic coefficients were determined in the CERES-Rice simulation model with the following parameters. P1(Time period or basic vegetative phase), P2O (Critical photoperiod), P2R (Photoperiodism coefficients), P5 (Grain filling duration coefficient), G1 (Spikelet number coefficient), G2 (Single grain weight), G3 (Tillering coefficients) and G4 (Temperature tolerance coefficient).

\subsection{Statistical analysis}

The analysis of variance (ANOVA) was performed by R/agricolae program (Mendiburu and Simon, 2007). Mean separation was done by Least Significant Difference (LSD) for split plot design to see the varietal differences. This study focused to simulate the effect of different temperatures on yield performed for phenology, grain yield, tops weight, leaf area index, harvest index, and tillers number. According to Kiniry et al. (1997) model evaluation was calculated by the Root Mean Square Error (RMSE) and d stat index (Willmott, 1982). The RMSEn gives the level of error associated with each evaluation between the observed and simulated values.

\section{Results and discussion}

\subsection{Soil analysis and discuss of the soil properties}

Soil physio-chemical and morphological properties were analyzed by using standard methods. Result (Table 1) indicated that by using Hydrometer method soil was medium sandy loam with sandy clay loam textured containing sand $72.60 \%$,

Table 1: Soil physical and chemical properties determined for net house soil

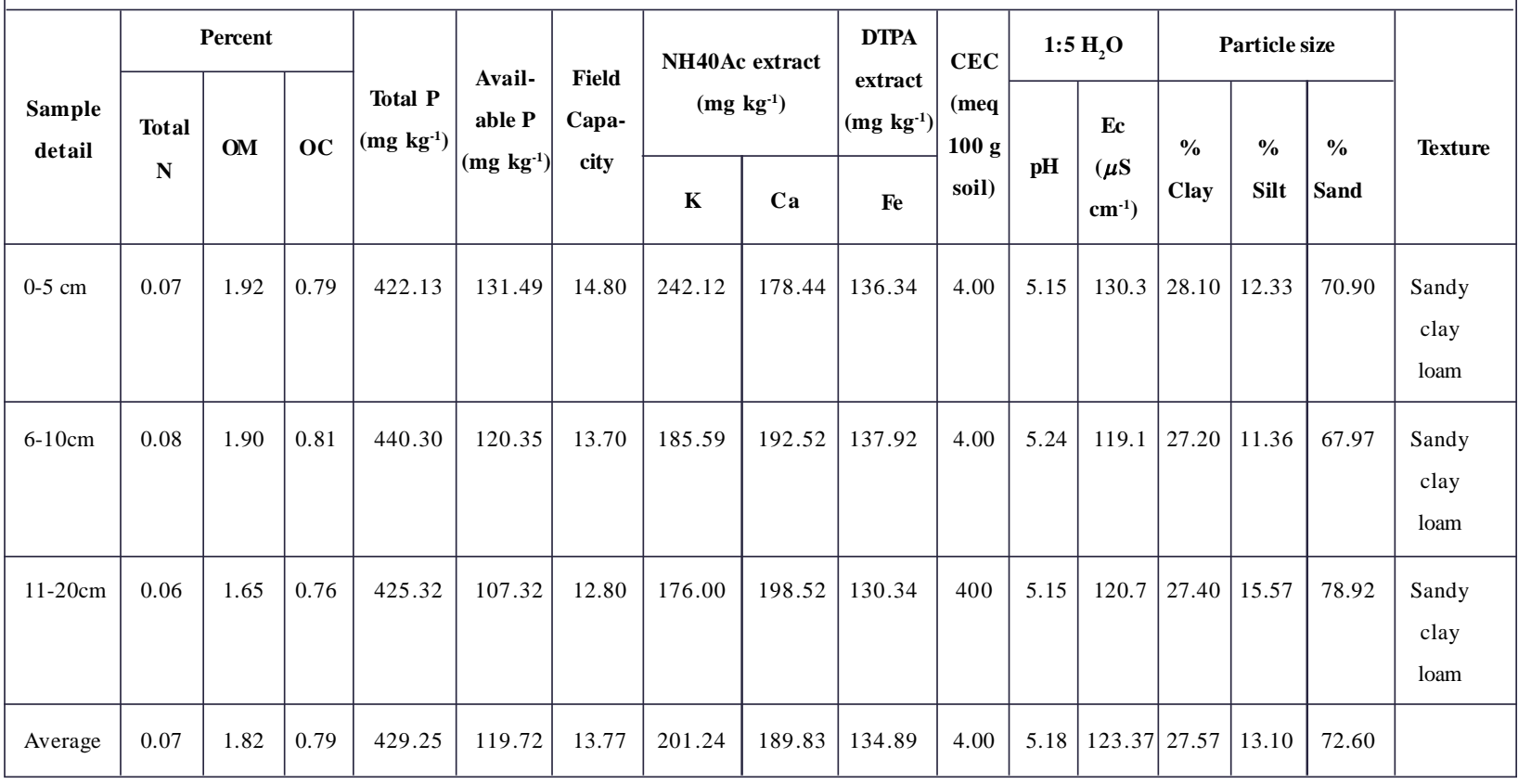


clay $27.57 \%$, silt $13.10 \%$. By using Gravimetric method field capacity of soil was measured $13.77 \%$. Soil containing average organic carbon was $0.79 \%$, organic matter $1.82 \%$, total nitrogen $0.07 \%$, total phosphorus $429.25 \%$, available phosphorus $119.72 \%$, available potassium $201.24 \%$, available calcium $189.83 \%$, available Fe $134.89 \%$, cation exchange capacity $4.00 \%$, exchangeable cation $123.37 \%$ and $\mathrm{pH}$ in water 5.18. Optimum dose of NPK fertilizer was applied at three splits with $35.50 \mathrm{gm} \mathrm{N}_{2}, 35.50 \mathrm{gm}_{2} \mathrm{O}_{5}$ and 35.50 gm of $\mathrm{K}_{2} \mathrm{O} @ 15-15-15 \mathrm{~kg} \mathrm{ha}^{-1}$. Various agronomic practices, e.g., weed and insect control were done manually. Insect pests were controlled by the application of $20 \mathrm{ml} / 1$ L Cypermethrin $10 \%$ w/v EC and $50 \mathrm{ml} / 1$ LBenfuracarb $20 \%$ w/v EC with water. Urea fertilizer (46-0-0) was applied at 30 days after planting.

\subsection{Weather condition analysis}

Impact of primary atmospheric variables on crop growth, development and grain production were rainfall, solar radiation, air temperatures, humidity, and precipitation. Reported by Kumari et al. (2017). Figure 1 showed that weather conditions had no visible variations. Here, the maximum and minimum temperatures ranged between 25 to $38^{\circ} \mathrm{C}$ and 20 to $22{ }^{\circ} \mathrm{C}$. Solar radiation ranged (10.2 to 20) $\mathrm{MJ} \mathrm{m}^{-2} \mathrm{~d}^{-1}$ hence appropriate solar radiation is useful especially during specific crop stages, crops' grain filling and maturity period in case adequate water supply (Villegas et al., 2016). Average rainfall ranged $(20-980 \mathrm{~mm}$ ) where highest was shown in the month of November to mid-December. After that January 151 month was second highest rainfall month near about $700 \mathrm{~mm}$ rainfall, respectively. Hatfield and Prueger (2015) noted in some cases, although the total annual amount of rainfall shows not much difference, the differences in its distribution can lead to risk of drought and flood having impact to rice yields. Optimum temperature required for rice growth is $25^{\circ} \mathrm{C}$ to $35^{\circ} \mathrm{C}$ and anthesis period is between $30^{\circ} \mathrm{C}$ to $33^{\circ} \mathrm{C}$ (Choudhury et al., 2018). Extreme high temperature beyond the average temperature hampered during experiment might have negative influence on crop growth and development have high risk for yield decrease (Hatfield and Prueger, 2015).

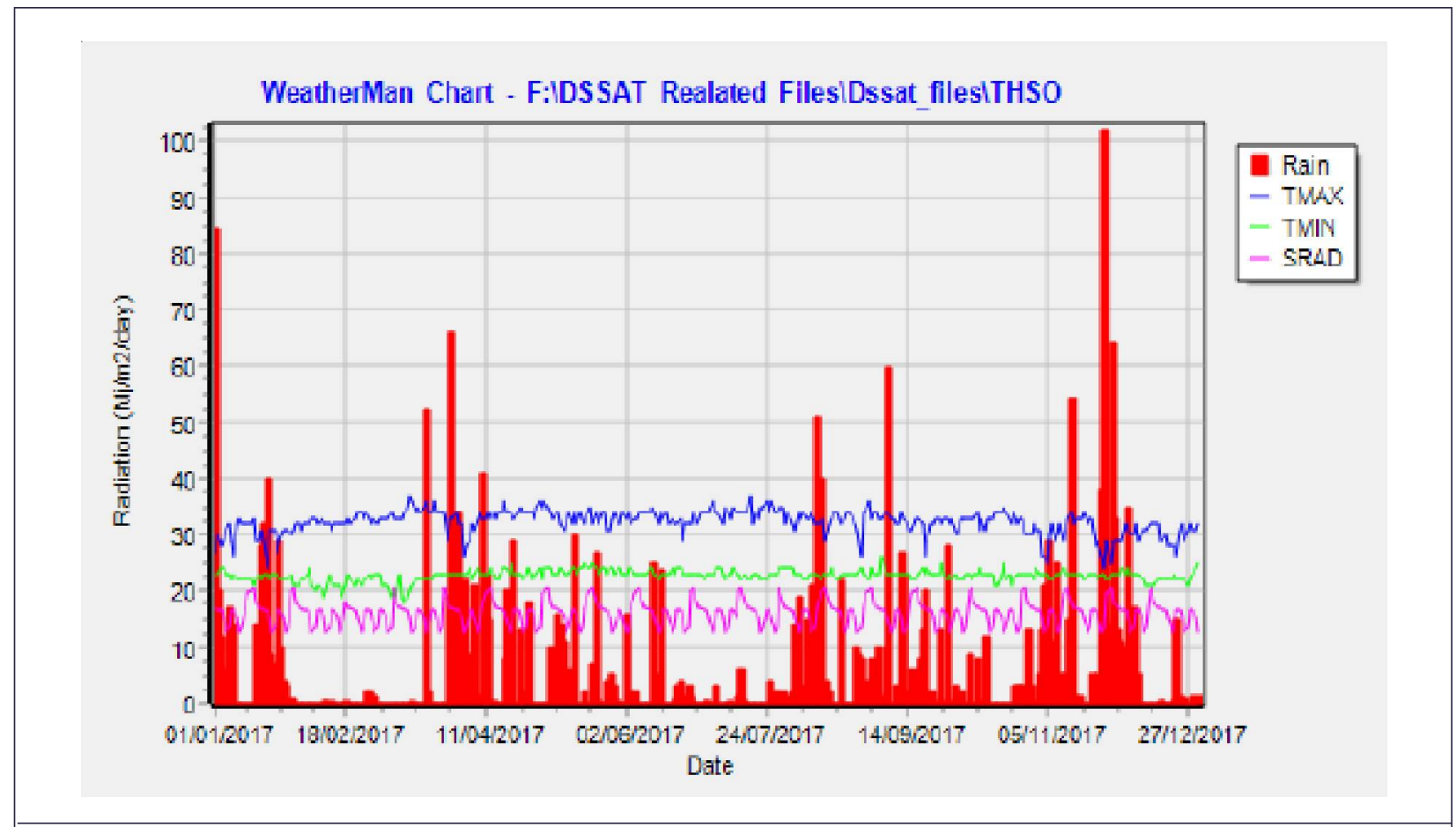

Figure 1: Mean daily maximum and minimum temperature, rainfall and solar radiation determined in 2017

\subsection{Calibration and evaluation of the model}

According to Jones et al. (2010), model calibration is the adjustment of genotype specific parameters so that simulated values compared well with observed field data. The genetic coefficients of CERES-Rice model were calibrated through time series observations collected from the experiment at three different temperatures $\left(28^{\circ} \mathrm{C}, 30^{\circ} \mathrm{C}\right.$ and $\left.32{ }^{\circ} \mathrm{C}\right)$ stages. Accuracy in simulation of yield, phenology and growth requires the appropriate coefficient (Choudhury et al., 2018). The genetic coefficients varied due to variation in their developmental rate at different phases (Lone et al., 2016). Based on experiments by repeated iterations until a close match between simulated and observed phenology and yield was obtained. 
Time series grain yield, tops weight, leaf area index, biomass and tillers number collected for genotypes Dawk Pa-yawm, Mai Tahk, Bow Leb Nahng, Dawk Kha 50 and Dawk Kahm. There was a good agreement between simulated and observed grain yield. Results showed juvenile or basic vegetative stage $(\mathrm{P} 1=128)$, critical photoperiod $(\mathrm{P} 2 \mathrm{O}=10.8)$, phasic development phase $(\mathrm{P} 2 \mathrm{R}=230)$ and time period $(\mathrm{P} 5=400)$ for grain filling were same for all the genotypes. But Potential spikelet number of coefficient (G1) was higher for most of the genotypes namely Dawk Kahm (82.9), Bow Leb Nahng (82.1), MaiTahk (80.8), Dawk Kha 50 (78.8) and Dawk Pa-yawm (68.3) very low for compared to others. Highest single grain weight (G2) was observed from the both genotypes Dawk Kahm (0.0300) and Dawk Kha 50 (0.0300) while lowest value from Dawk Pa-yawm (0.020). Highest tillering coefficient (G3) was noted for Dawk Kahm (0.89) and the lowest was for Bow Leb Nahng (0.33). Consequently, highest temperature tolerance coefficient (G4) was observed from genotype Dawk Kahm (1.09) and the lowest one from Dawk Pa-yawm (0.78). So, Dawk Kahm genotype was the most temperature tolerant among the others. All the calibrated genetic coefficients were shown in Table 2.

Table 2: Calibrated Genetic coefficient values for 5 upland rice genotypes

\begin{tabular}{|c|c|c|c|c|c|c|c|c|}
\hline \multicolumn{9}{|c|}{ Genetic coefficient values } \\
\hline Genotypes & P1 & $\mathbf{P 2 O}$ & P2 R & P5 & G1 & G2 & G3 & G4 \\
\hline Bow Leb Nahng & 128.0 & 10.8 & 230.0 & 400.0 & 82.1 & 0.024 & 0.33 & 0.98 \\
\hline Dawk Kahm & 128.0 & 10.8 & 230.0 & 400.0 & 82.9 & 0.030 & 0.89 & 1.09 \\
\hline Dawk Kha-50 & 128.0 & 10.8 & 230.0 & 400.0 & 78.8 & 0.030 & 0.61 & 0.90 \\
\hline Mai Tahk & 128.0 & 10.8 & 230.0 & 400.0 & 80.8 & 0.029 & 0.61 & 0.95 \\
\hline Dawk Pa-yawm & 128.0 & 10.8 & 230.0 & 400.0 & 68.3 & 0.020 & 0.37 & 0.78 \\
\hline \multicolumn{9}{|c|}{$\begin{array}{l}\text { Note: [P1 (Time period or basic vegetative phase), P2O (Critical photoperiod), P2R (Photoperiodism coefficients), P5 (Grain } \\
\text { filling duration coefficient), G1 (Spikelet number coefficient), G2 (Single grain weight), G3 (Tillering coefficients), and } \\
\text { G4 (Temperature tolerance coefficient) }\end{array}$} \\
\hline
\end{tabular}

\subsection{Analysis the result of yield and yield attributes}

\subsubsection{Analysis of variance}

ANOVA results (Table 3 ) for phenological traits using LSD test $(p<0.05$ and $p<0.01)$ revealed that some traits showed highly significant differences with temperatures and genotypes. Grain yield, tops weight, harvest index, flowering date,

Table 3: Results of mean squares from analysis of variance for 5 upland rice genotypes

\begin{tabular}{|c|c|c|c|c|c|c|c|c|}
\hline \multirow[b]{2}{*}{ Source } & \multicolumn{8}{|c|}{ Mean Squares } \\
\hline & df & TN & TW & LAI & HI & GY & FD & MD \\
\hline Replication & 2 & 3.82 & 6897576 & 0.00054 & 0.00037 & 1123827 & 287.20 & 37.70 \\
\hline Temperature (T) & 2 & 8.96 & $7714899 * *$ & 0.0017 & $0.00050 * *$ & $21101974^{* *}$ & $1488.40 * *$ & $4.29 * *$ \\
\hline Error (a) & 4 & 3.46 & $1909466^{* * *}$ & 0.0003 & $0.00034 * *$ & $895471 * *$ & $248.000 * *$ & $19.00 * *$ \\
\hline Genotypes (G) & 4 & $26360 * *$ & $1412628 * *$ & $0.0310 * *$ & $0.17674 * *$ & $8577099 * *$ & $2.00 * *$ & $9.48 * *$ \\
\hline $\mathrm{T} \times \mathrm{G}$ & 8 & 2.20 & 275655 & 0.0017 & 0.00008 & $210410 * *$ & $5.01 * *$ & $1.844 * *$ \\
\hline Error (b) & 24 & 5.99 & 123482 & 0.0019 & 0.00012 & 61252 & 0.82 & 1.94 \\
\hline CV\% (a) & & 3.41 & 16.67 & 1.04 & 3.06 & 16.51 & 17.28 & 3.87 \\
\hline CV\% (b) & & 4.49 & 4.06 & 1.71 & 1.80 & 4.32 & 0.99 & 1.27 \\
\hline
\end{tabular}

Note: Here, TN = Tillers Number, TW = Tops Weight, LAI = Leaf Area Index, HI $=$ Harvest Index, GY = Grain Yield, FD = Flowering Date and MD = Maturity Date; $*=$ significant at $5 \%$ level; and $* *=$ significant at $1 \%$ level. 
and maturity date was highly significantly affected by temperatures. Non-significant difference for tillers number, and leaf area index occurred possibly due to the optimum input of temperatures at the early stage. Result showed that grain yield at each treatment reduced with delay in planting date, i.e., flowering and maturity date. Whereas all the phenological traits such as tillers number, tops weight, leaf area index, harvest index, grain yield, flowering and maturity date had highly significant variation by the different genotypes. Grain yield, flowering date and maturity date had interaction effects between temperature and genotype.

\subsection{Analysis of mean comparison for phenotypic parameters}

Tables 4 showed mean comparison for the phenotypic traits of the genotypes. Results showed that Mai Tahk genotype had highest tiller number 78.00 no, with low tops weight $7610.10 \mathrm{gm}$, leaf area index 1.60, and grain yield $3991.00 \mathrm{k} / \mathrm{g}$ ha. It seemed that this genotype was highly affected for all the temperature stages and highly temperature sensitive genotype. On the other hand, Dawk Kahm genotype had lowest tillers number 65.00 no, with highest tops weight 8404.00 gm, leaf area index 1.83, harvest index 0.69 , highest maturity date 115 days and grain yield $6231.00 \mathrm{~kg} / \mathrm{ha}$. And Dawk Kha genotype had second lowest tillers number 77.00 no, with second highest tops weight $8313.40 \mathrm{gm}$, leaf area index 1.73 , highest maturity date 109 days and highest grain yield $6133.20 \mathrm{~kg} / \mathrm{ha}$. The finding was very much similar with (Singh et al., 2014). The simulated phenology and yield were found in agreement with observed data suggesting that calibrated model can be used suitably with observed soil, crop management and weather parameters.

Table 4: Results of mean comparison for 5 upland rice genotypes

\begin{tabular}{|l|c|c|c|c|c|c|c|}
\hline \multicolumn{7}{|c|}{ Triats } \\
\hline Genotypes & TN (no) & TW (gm) & LAI & HI & GY (kgha $)^{-1}$ & FD (day) & MD (day) \\
\hline Bow Leb Nahng & 73.00 & 8289.30 & 1.69 & 0.65 & 5535.00 & 91 & 109 \\
\hline Dawk Kahm & 65.00 & 8404.00 & 1.83 & 0.69 & 6231.00 & 95 & 115 \\
\hline Dawk Kha & 77.00 & 8313.40 & 1.73 & 0.42 & 6133.20 & 91 & 109 \\
\hline Mai Tahk & 78.00 & 7610.10 & 1.60 & 0.62 & 3991.00 & 92 & 109 \\
\hline Dawk Pa-yawm & 76.00 & 8189.30 & 1.81 & 0.69 & 6067.80 & 91 & 112 \\
\hline LSD $_{0.05}$ & 2.38 & 327.75 & 0.03 & 0.010 & 240.79 & - & 1.35 \\
\hline LSD $_{0.01}$ & 3.23 & 444.16 & 0.04 & 0.014 & 326.31 & - & 1.84 \\
\hline
\end{tabular}

Note: Here, $\mathrm{TN}=$ Tillers Number, $\mathrm{TW}=$ Tops Weight, LAI $=$ Leaf Area Index, HI $=$ Harvest Index, GY $=$ Grain Yield, FD = Flowering Date and MD = Maturity Date.

\subsection{Simulated effect of temperature on grain yield}

After calibration the model, comparison was made between simulated and observed grain yield at $28{ }^{\circ} \mathrm{C}, 30^{\circ} \mathrm{C}$ and $32{ }^{\circ} \mathrm{C}$ temperature stages with time (Table 5). The close agreement between observed and simulated values of grain yield for all the genotypes shown in this study. Results showed Dawk kahm and Dawk Kha were the best genotypes due to increasing simulated grain yield and best performed with the moderate temperature at $30{ }^{\circ} \mathrm{C}$ (Dawk Kahm $6700 \mathrm{~kg} \mathrm{ha}^{-1}$ and Dawk Kha $6300 \mathrm{~kg} \mathrm{ha}^{-1}$ ). Whereas at $32{ }^{\circ} \mathrm{C}$ temperature stage, a large variation for all the genotypes decreased in yield with the maximum temperature increased. Highest reduction in simulated yield was recorded for Bow Leb Nahng genotype $\left(3180 \mathrm{~kg} / \mathrm{ha}\right.$ at $28^{\circ} \mathrm{C}, 3250 \mathrm{~kg} / \mathrm{ha}$ at $30^{\circ} \mathrm{C}$ and $3094 \mathrm{~kg} / \mathrm{ha}$ at $\left.32^{\circ} \mathrm{C}\right)$ compared to others with best performed while minimum temperature increased at high temperature $\left(30^{\circ} \mathrm{C}\right)$ stage. Similar finding was shown by Shamin et al. (2010), Singh et al. (2014).

The simulated yield of upland rice ranged were (3094 to 6700) $\mathrm{kg} / \mathrm{h}$ a respectively. Maniruzzaman et al. (2018) reported grain yield deceased with increase in temperatures at $28^{\circ} \mathrm{C}, 30{ }^{\circ} \mathrm{C}$ and $32^{\circ} \mathrm{C}$. This indicated that rice production will be decreasing trends in future if climate smart practices are not adopted. Grain yield reduction was higher with short and medium growth duration rice genotypes compared to long duration Bow Leb Nahng, Mai Tahk and Dawk Pa-yawm. In general, the effect of increased temperature would be negative because of increasing respiration and shortened vegetative and grain filling period reported by Jerry L Hatfield, (2016). All though major rice models using DSSAT indicated about $5 \%$ yield reduction for every degree rise in mean temperature (Dias et al., 2016) estimated 25\%-35\% yield reduction. 
Table 5: Results of comparison between measured and simulated grain yield of five upland rice genotypes at varying temperature levels with the DSSAT CERES-Rice model

\begin{tabular}{|c|c|c|c|c|c|c|}
\hline \multirow{3}{*}{ Genotypes } & \multicolumn{6}{|c|}{ Triats } \\
\hline & \multicolumn{2}{|c|}{$28{ }^{\circ} \mathrm{C}$} & \multicolumn{2}{|c|}{$30{ }^{\circ} \mathrm{C}$} & \multicolumn{2}{|c|}{$32{ }^{\circ} \mathrm{C}$} \\
\hline & Measured & Simulated & Measured & Simulated & Measured & Simulated \\
\hline Bow Leb Nahng & 4829 & 3180 & 3808 & 3250 & 3335 & 3094 \\
\hline Dawk Kahm & 5857 & 6667 & 7762 & 6700 & 5074 & 6460 \\
\hline Dawk Kha & 5947 & 6230 & 7431 & 6300 & 5021 & 5230 \\
\hline Mai Tahk & 7532 & 5804 & 5920 & 5667 & 5055 & 5600 \\
\hline Dawk Pa-yawm & 7323 & 6303 & 5983 & 6234 & 4897 & 4239 \\
\hline
\end{tabular}

\subsection{Calibration results of DSSAT model}

Model calibration is an important step for the adjustment of simulations results that can be well compared with observations for the ensuring of crop growth and yield parameters. Collected data from experiment was used for calibration. Simulation results showed superior performance for top weight $(\mathrm{kg}[\mathrm{dm}] / \mathrm{ha})$, grain weight $(\mathrm{kg}[\mathrm{dm}] / \mathrm{ha})$, leaf area index, tiller number $\left(\mathrm{no} / \mathrm{m}^{2}\right)$, harvest index (grain/top) and there was a strong agreement between simulated and observed values for phenology and yield parameters (Figures 2, 3, 4, 5 and 6).

\subsection{Simulated effect of temperatures on tops weight (CWAD)}

Simulation result revealed that tops weight $(\mathrm{kg}[\mathrm{dm}] / \mathrm{ha})$ could be predict well. Predict yield was plotted against observed yields (Figure 2). Top weight ( $\mathrm{kg}[\mathrm{dm}] / \mathrm{ha}$ ) simulate with less accuracy as indicate by the values of RMSE were $925.60,855.33$, and 612.67 with d-stat $0.77,0.76$, and 0.86 , respectively. The yield equation thus obtained measured mean tops weight $7618.53(\mathrm{~kg}[\mathrm{dm}] / \mathrm{ha}), \mathrm{nRMSE}=14.28$ indicated that had a poorest agreement by both observed and simulated values. Adjustment with $30^{\circ} \mathrm{C}$ had a better agreement for tops weight with lower d-stat value among the three temperature stages for the genotypes. So, model performance was poor for tops weight. Pooled of tops weight indicated that the forecasting efficiency.

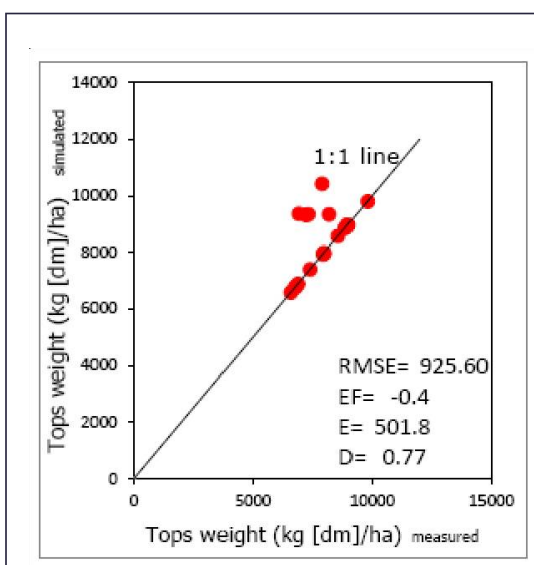

(a)

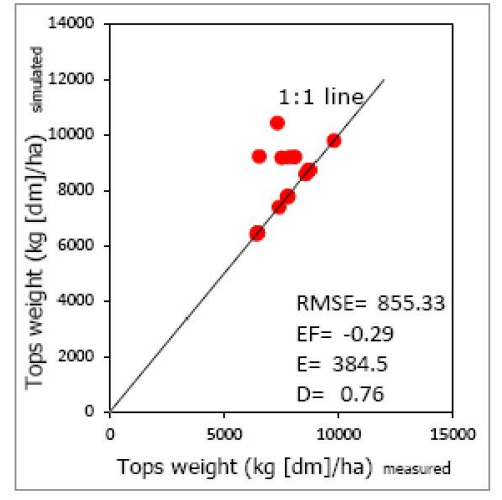

(b)

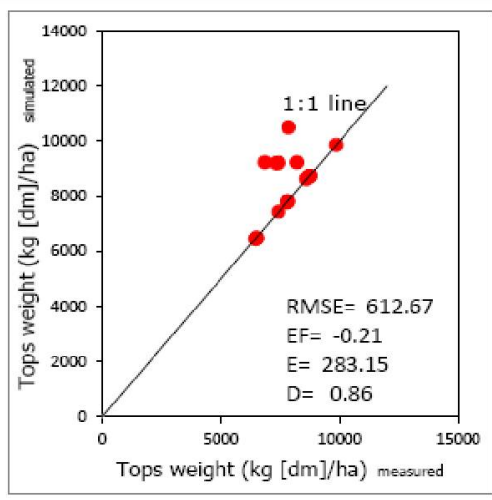

(c)

Figure 2: Simulated versus measured tops weight $\left(2 \mathrm{a}\right.$ at $\left.28{ }^{\circ} \mathrm{C}\right),\left(2 \mathrm{~b}\right.$ at $\left.30{ }^{\circ} \mathrm{C}\right),\left(2 \mathrm{c}\right.$ at $\left.32{ }^{\circ} \mathrm{C}\right)$.

\subsection{Simulated effect of temperatures on grain weight (GWAD)}

Simulation result showed that grain weight $(\mathrm{kg}[\mathrm{dm}] /$ ha) could be predict well. Predict yield was plotted in 1:1 graph (Figure 3). Grain weights simulate with less accuracy at $28^{\circ} \mathrm{C}, 30^{\circ} \mathrm{C}$ and $32^{\circ} \mathrm{C}$ temperature stages. Hence, RMSE values 


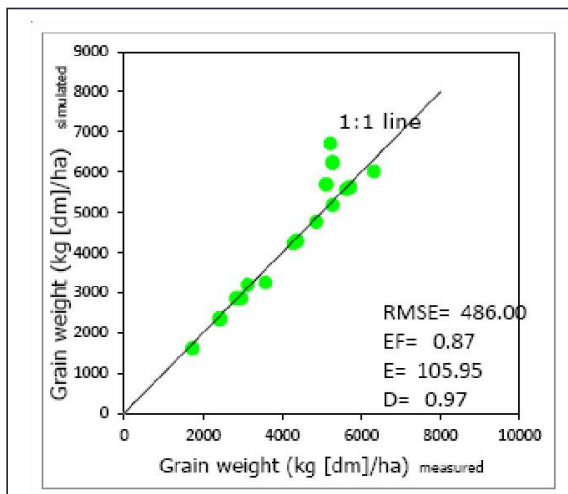

(a)

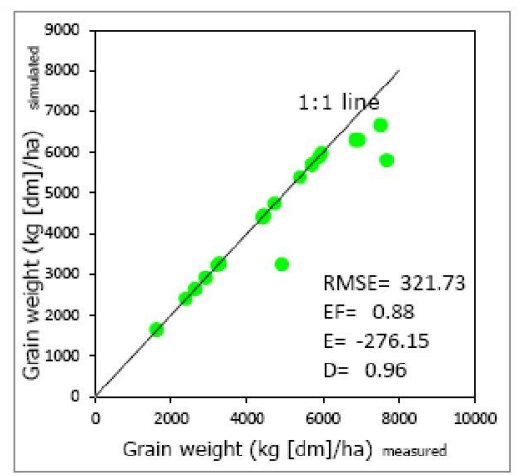

(b)

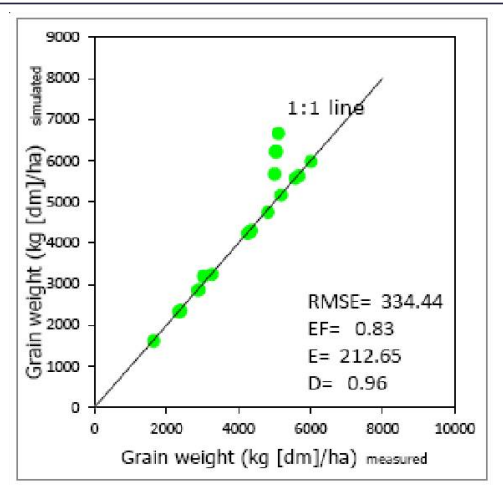

(c)

Figure 3: Simulated versus measured grain weight (3a at $\left.28{ }^{\circ} \mathrm{C}\right),\left(3 \mathrm{~b}\right.$ at $\left.30{ }^{\circ} \mathrm{C}\right),\left(3 \mathrm{c}\right.$ at $\left.32{ }^{\circ} \mathrm{C}\right)$

were 321.73334 .44 and 486.00 with observed d-index $0.96,0.96,0.97$, respectively. Measured mean grain weight $4289.83(\mathrm{~kg}$ $[\mathrm{dm}] / \mathrm{ha}$ ) with $\mathrm{nRMSE}=14.80$ which showed that very poorest agreement for simulated and observed values. Adjustment with $28{ }^{\circ} \mathrm{C}$ and $30^{\circ} \mathrm{C}$ both had a better agreement for grains weight with lower d-stat value among the three temperature stages for the genotypes So, model performance was good for grain weight supported by Lone et al. (2016).

\subsection{Simulated effect of temperatures on leaf area index (LAID)}

Simulation results revealed that the leaf area index could be predicted well as well as excellent (Figure 4). 1:1 graph showed that the predicted leaf areas index was plotted against the observed data. Simulated LAI was comparable with the observed values. RMSE data 1.06, 1.03, and 1.04. The d-index values thus obtained $0.99,1$ and 1 , respectively. Measured mean leaf area index $=2.14$ with $\mathrm{nRMSE}=2.04$ indicated that very excellent agreement for simulated and observed values where similar trend was followed by both the observed and simulated values. Hence, $28{ }^{\circ} \mathrm{C}$ had an adjustment excellent agreement for leaf area index with lower d-stat values among the three temperature stages for the genotypes. The result similar with the findings of Hussain et al. (2018).

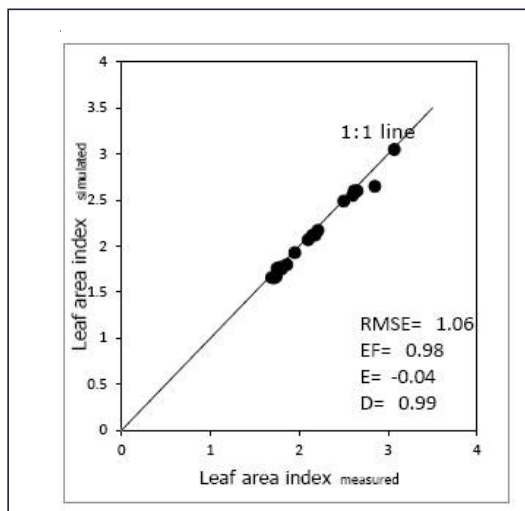

(a)

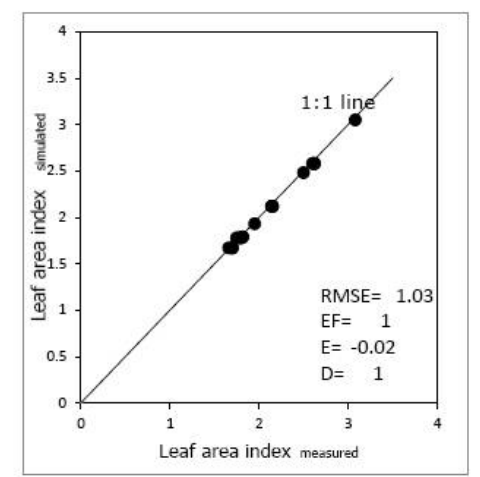

(b)

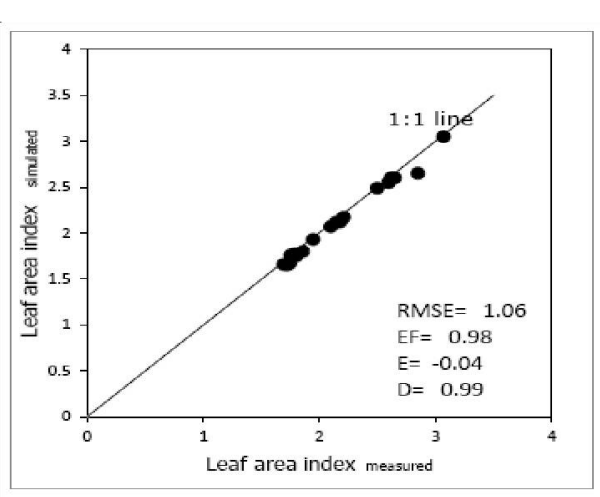

(c)

Figure 4: Simulated versus measured leaf area index (4a at $\left.28{ }^{\circ} \mathrm{C}\right),\left(4 \mathrm{~b}\right.$ at $\left.30{ }^{\circ} \mathrm{C}\right),\left(4 \mathrm{c}\right.$ at $\left.32{ }^{\circ} \mathrm{C}\right)$

\subsection{Simulated effect of temperatures on tillers number (T\#AD)}

Fiure 5 showed that tillers number $\left(\mathrm{no} / \mathrm{m}^{2}\right)$ could be predicted excellently with 1:1 graph where predicted 258 tillers number plotted against observed data. With three temperature stages RMSE values were 1.20, 1.02, and 1.20 with d-index $=1,1$, and 1 , respectively. Measured mean tillers number $=56.45\left(\mathrm{no} / \mathrm{m}^{2}\right)$ with $\mathrm{nRMSE}=3.07$ indicated that very excellent agreement with all the temperatures schedule and similar trend was followed by both the observed and simulated values for tillers number. This result is supported by Hussain et al. (2018) representing tillers number response to grain yield, i.e., important yield contributing environmental factors. 


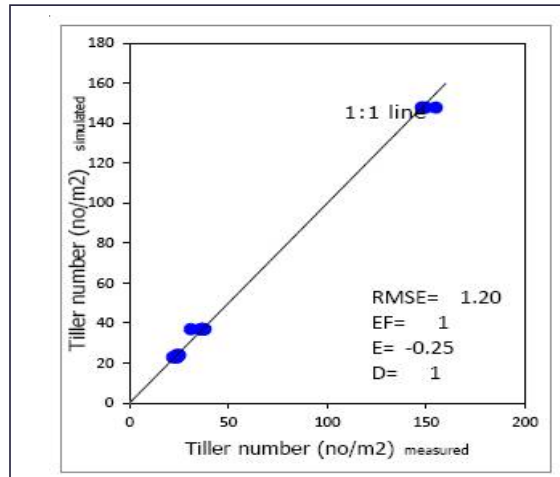

(a)

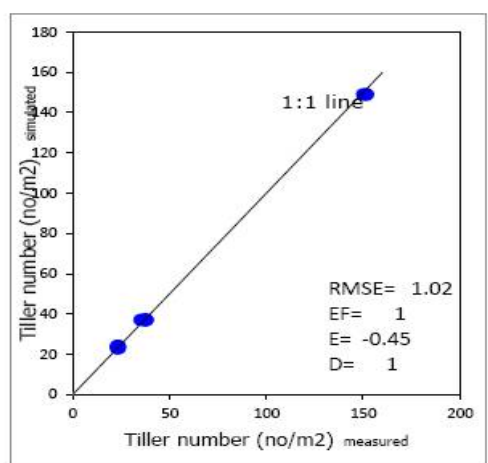

(b)

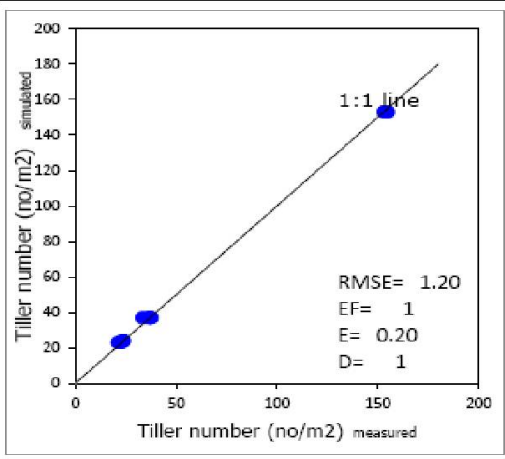

(c)

Figure 5: Simulated versus measured tillers number $\left(5 \mathrm{a}\right.$ at $\left.28{ }^{\circ} \mathrm{C}\right),\left(5 \mathrm{~b}\right.$ at $\left.30{ }^{\circ} \mathrm{C}\right),\left(5 \mathrm{c}\right.$ at $\left.32{ }^{\circ} \mathrm{C}\right)$

\subsection{Simulated effect of temperatures on harvest index (HIAD)}

Figure 6 showed that harvest index (grain/top) could be well with 1:1 graph where predicted tillers number plotted against observed data. Whereas, excellent agreement was observed for harvest index, for the temperature stage $28^{\circ} \mathrm{C}$ with lower RMSE value was 0.01 and maximum d-index 1 observed, respectively compared to $30^{\circ} \mathrm{C}$ and $32^{\circ} \mathrm{C}$ with RMSE value 0.02 and 1.02. Measured mean harvest index $269=0.52$ (grain/top) with nRMSE $=3.22$ indicated that poor agreement for simulated and observed values where similar trend was followed by both the observed and simulated values for harvest index and supported by Hussain et al. (2018).

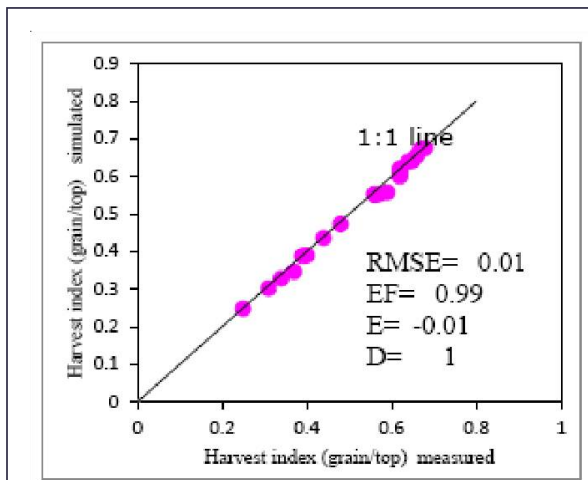

(a)

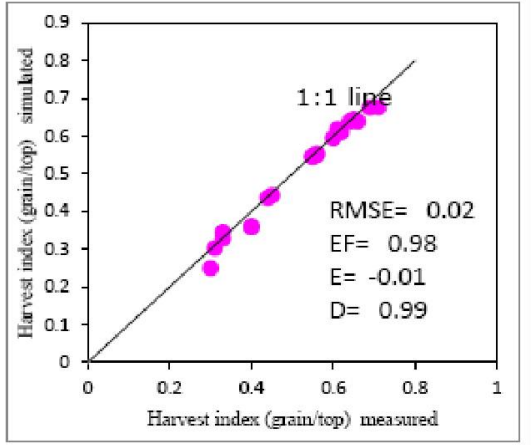

(b)

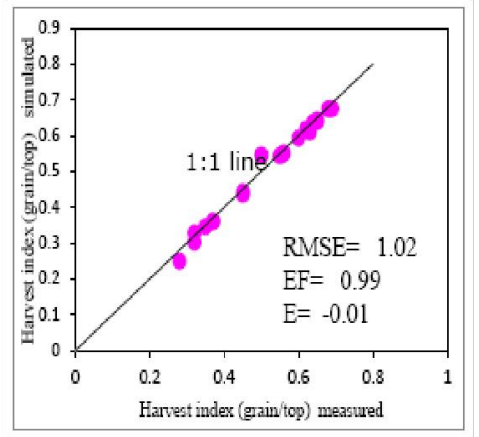

(c)

Figure 6: Simulated versus measured harvest index $\left(6 \mathrm{a}\right.$ at $\left.28{ }^{\circ} \mathrm{C}\right),\left(6 \mathrm{~b}\right.$ at $\left.30{ }^{\circ} \mathrm{C}\right),\left(6 \mathrm{c}\right.$ at $\left.32{ }^{\circ} \mathrm{C}\right)$

\section{Conclusion}

Evaluation of model showed their level of reliability of simulations with different temperatures for phenology and yield attributes of upland rice genotypes. It showed that grain weight, tillers number, leaf area index and harvest index had an excellent agreement with the observed value. Result revealed that highest simulated grain yield bearing genotype was Dawk Kahm $6700 \mathrm{~kg} / \mathrm{ha}$ with $30^{\circ} \mathrm{C}$. Simulation result indicated that phenological traits like grain weight, leaf area index, tiller number and harvest index very well predicted by CSM-CERES-Rice model and have an excellent agreement. The simulated yield of aromatic rice ranges $(2160-4770) \mathrm{kg} / \mathrm{ha}$. Overall, it concludes that CSM-CERES-Rice model can be safely more used as a tool for simulating effect of temperatures on the growth and yield of aromatic rice under different agronomic and changing climatic conditions.

\section{Acknowledgment}

This paper was supported by government budget of Prince of Songkla University (NAT610046S) and the Higher Education Research Promotion with Thailand's Education Hub for ASEAN Countries (TEH-AC) Project Office. The authors thank, Graduate School and Faculty of Natural Resources, Prince of Songkla University, Hat Yai campus, Thailand for financial support. 


\section{References}

Amirjani, M.R. (2011). Effect of salinity stress on growth, sugar content, pigments, and enzyme activity of rice. International Journal of Botany. 7, 73-81.

Araus, J.L. and Slafer, G.A. (2011). Crop Stress Management and Global Climate Change. CABI 875 Massachusetts Avenue, Cambridge, MA 02139 USA.

Bridhikitti, A. and Overcamp, T.J. (2011). Estimation of Southeast Asian rice paddy areas with different 293 ecosystems from moderate-resolution satellite imagery. Agriculture, Ecology \& Environment Journal. 146(2012), 113-120.

Chen, C., Wang, E. and Yu, Q. (2010). Modeling the effects of climate variability and water management on crop water productivity and water balance in the North China Plain. Agric. Water. Manag. 97(8), 1175-1184. Available from: https://doi.org/10.1016/j. ag wat. 2008.11.012

Choudhury, A.K., Ishtiaque, S., Sen, R., Jahan, M.A.H.S., Akhter, S., Ahmed, F., Biswas, J.C., Manirruzaman, M., Hossain, M.B., Miah, M.M., Rahman, M.M., Zahan, T., Khan, A.S.M.M.R. and Kalra, N. (2018). Calibration and validation of DSSAT model for simulating wheat yield in Bangladesh. The Saudi Journal of Life Sciences. 3(4), 356-364.

Dias, M.P.N.M., Navaratne, C.M., Weerasinghe, K.D.N. and Hettiarachachi, R.H.A.N. (2016). Application of DSSAT crop simulation model to identify the changes of rice growth and yield in Nilwala River basin for mid-centuries under changing climatic conditions. Procedia. Food. Science. 6, 159-163.

Fahad, S. , Bajwa, A.A., Nazir, U. , Anjum, S.A., Farooq, A., Zohaib, A. , Sadia, S., Wajid Nasim, W., Adkins ,S., Saud, S., Ihsan, M.Z., Alharby, H., Wu,C. , Wang, D. and Jianliang Huang, J. (2017). Crop production under drought and heat stress: Plant responses and management options. Journal Frontiers in Plant Science. 8, 1-16.

FAO, (2012). Report of the International Rice Commission, Twentieth Session. Bangkok, Thailand, 23-26 July 2012. FAO, Rome, $46 \mathrm{p}$.

Fazal, S.A. and Wahab, S.A. (2013). Economic impact of climate change on agricultural sector: A review. Journal of Transformative Entrepreneurship. 1(1), 39-49.

Goyal, V., Malik, R.S. and Jhorar, B.S. (2012). Modeling groundwater recharge from the lined farm canal under shallow water table condition. Indian Journal of Agricultural Research.46(3), 217-225.

Hatfield, J.L. and Prueger, J.H. (2015). Temperature extremes: Effect on plant growth and development. Weather and Climate Extremes (2015): 1-7. http://dx.doi.org/10.1016/j.wace.2015.08.001i

Hussain, T., Anothai, J., Nualsri, C. and Soonsuwon, W. (2018). Application of CSM-CERES-Rice in scheduling irrigation and simulating effect of drought stress on upland rice yield. Indian Journal of Agricultural Research. 52(2), 140145.

[ICASA] International Consortium for Agricultural Systems Applications. (2011). DSSAT software, 2011. Available from: http:// www.icasa.net

[IPCC] Inter governmental Panel on Climate Change. (2013). Summary for Policymakers. In: Climate Change 2013: The Physical Science Basis. Contribution of Working Group I to the Fifth Assessment Report of the Intergovernmental panel on Climate Change [ Stocker TF, Qin D, Plattner GK, Tignor M, Allen SK, Boschung J, Nauels A, Xia Y, Bex V and Midgley PM, eds. Cambridge University Press, Cambridge, United Kingdom and New York, NY, USA.

Jalota, S.K. (2010). Integrated effect of transplanting date, cultivar and irrigation on yield, water saving and water productivity of rice (Oryza sativa L.) in Indian Punjab: field and simulation study. Agricultural Water Management Journal. 96, 1096-1104.

Jat, S.R., Gulati, I.J., Soni, M.L., Kumawat, A., Yadava, N.D., Nangia, V., Glazirina, M. and Rathor, V.S. (2017). Water productivity and yield analysis of groundnut using crop syst simulation model in hyper arid partially irrigated zone of Rajasthan. Legume Research. 40(4), 1-6. Available from: https://doi.org/10.18805/lr.v40i04.9003

Jerry L. Hatfield. (2016). Increased temperatures have dramatic effects on growth and grain yield of three maize hybrids. Agricultural \& Environmental Letters. 2016, 1-5. doi:10.2134/ael2015.10.0006

Jones, J., Hoogenboom, G., Wilken, P., Porter, C. and Tsuji, G. (2010). Decision support system for agrotechnology transfer version 4.5. Volume 3. DSSAT v4.5: ICASA Tools. Honolulu, HI: University of Hawaii.

Kiniry, J., Williams, R., Vanderlip, J., Atwood, D., Muuliken, W., Cox, H. and Weibold, W. (1997). Evaluation of two maize models for nine U.S. locations. Agronomy Journal. (89), 421-426. 
Kumari, P., Kumar, P.V., Kumar, R., wadood, A. and Tirkey, D.A. (2017). Effect of weather on grain yield of direct seeded upland rice varieties in Jharkhand, India. Indian Journal of Agricultural Research. 51(6), 562-567. Available from: https://doi.org/10.18805/IJARe.A-4714

Lizaso, J., Boote, K., Jones, J., Porter, C., Echarte, L., Westgate, M. and Sonohat, G. (2011). CSM-IXIM: A new rice simulation model for DSSAT Version 4.5. biometry, modeling and statistics. Agronomy Journal. 103. Available from: 766-779. http://dx.doi.org/10.2134/agronj 2010. 0423

Lone, B.A., Qayoom S., Rajouri, R.A.R.S. and Panotra, N. (2016). Validation for growth and productivity of various rice cultivars under temperate conditions of Kashmir valley using CERES-Rice model. Proceedings of the $10^{\text {th }}$ INDIA Com; INDIACom-2016; IEEE Conference ID: 37465, 2016, 3rd International Conference on "Computing for Sustainable Global Development”, 16th-18th March, 2016 Bharati Vidyapeeth's Institute of Computer Applications and Management (BVICAM), New Delhi (INDIA).

Maniruzzaman, M., Hossain, M.B., Biswas, J.C. and Haque, M.M. (2018). Effect of elevated air temperature and carbon dioxide levels on dry season irrigated rice productivity in Bangladesh. American. Journal of Plant Science. 8(9), $1557-1576$.

Mendiburu, F.D. and Simon, R. (2007). Agricolae-a free statistical library for agricultural research. Ames, IA: Iowa State University.

Nayak, A.K., Shahid, M., Nayak, A.D., Dhal, B., Moharana, K.C., Mondal, B., Tripathi, R., Mohapatra, S.D., Bhattacharyya, P., Jambhulkar, N.N., Shukla, A.K., Fitton, N., Smith, P. and Pathak, H. (2019). Assessment of ecosystem services of rice farms in eastern India. Ecological Processes. pages 1-16. https://doi.org/10.1186/s13717-019-0189-1

Nishad, A., Mishra, A.N., Chaudhari, Rajan., Aryan, R.K. and Katiyar, P. (2018). Effect of temperature on growth and yield of rice (Oryza sativa L.) cultivars. International Journal of Chemical Studies. 6(5), 1381-1383.

Reidsma, P., Wert, F., Lansink, O.A. and Leemans, R. (2010). Adaptation to climate change and climate variability in European agriculture: The importance of farm level responses. European Journal of A gronomy. 32(1), 91-102.

Shamin, M., Patel, R.H, Pandey, V. and Lunagaria, M.M. (2010). Sensitivity of CERES-Rice model to different environmental parameters on the productivity of aromatic rice in middle Gujarat. International Journal of Agricultural Technology. 12(2), 213-216.

Singh, P. K., Rathore, L. S, Singh, K.K. and Baxla, A. (2014). Modelling the effect of planting date on Rice (Oryza sativa L.) crop in Sabour region of Bihar using DSSAT v3.5 crop simulation model. Mausam. 61(1), 75-80.

Soler, C., Snetelhas, P. and Hoogenboom, G. (2017). Application of the CSCERES-Maize model for planting date evaluation and yield forecasting for maize grown off-season in a subtropical environment. European Journal of Agronomy. 27(2-4), 165-177. Available from: http://dx.doi.org/10.1016/j.eja.2007.03.002

Villegas, D., Alfaro, C., Ammar, K., Catedra, M.M., Crossa, L.F., Morai, G.D. and Royo. (2016). Day length, temperature and solar radiation effects on the phenology and yield formation of spring durum wheat. Journal of Agronomy and Crop Science. 203-216.

Wang, J., Mendelsohn, R., Dinar, A., Huang, J., Rozelle, S. and Zhang, L. (2009). The Impact of Climate Change on China's Agriculture. Agricultural Economics. 40: 323-337. Available from: https://doi.org/10.1111/j.1574-0862.2009.00379.x

Willmott, C. J. (1982). Some comments on the evaluation of model performance. Bull. Amer. Met. Soc. 63, 1309-1369.

Zhang, X. and Yang, F. (2012). R Clim Dex 1.0 User Manual. Climate Research Branch, Environ Canada, Downsview.

Cite this article as: Shams Shaila Islam, Jirawat Sanitchon and Ahmed Khairul Hasan (2021). Rice phenology and growth simulation using DSSAT- CERES-Rice crop model under the different temperatures changing with climatic condition. International Journal of Agricultural Sciences and Technology. 1(2), 1-11. doi: 10.51483/ IJAGST.1.2.2021.1-11. 